\title{
THE INFLUENCE OF WORK ENVIRONMENT TOWARDS TURNOVER INTENTION OF EMPLOYEE OF 4 STAR HOTELS IN PADANG CITY
}

\author{
Ira Meirina, Feri Ferdian, Pasaribu, Hijriyantomi Suyuthie. \\ Universitas Negeri Padang, Indonesia, \\ Universiti Terknologi MARA, Malaysia, \\ Universitas Negeri Padang, Indonesia, \\ Universitas Negeri Padang, Indonesia. \\ meirinaira@yahoo.com
}

\begin{abstract}
The purpose of this study was to analyze the influence of the work environment towards turnover intention of 4-star hotel employees in Padang City. This type of research is quantitative descriptive with a causal associative approach. The population in this study was 796 people consisting of all 4-star hotel employees in Padang City. The sample is 251 people using proportional random sampling technique. The data analysis technique used is simple linear regression analysis. The results of the study show that $\mathrm{F}$ counts with sig. $0,000<0,05$, then the work environment variable has a significant influence on employee turnover intention. Next, R Square is 0.309. This means that the work environment affects employee turnover intention by $30.9 \%$ and the rest is influenced by other factors such as salary, work stress, job satisfaction. Regression coefficient value if $\mathrm{Y}=\mathrm{a}+\mathrm{bX}=$ $17,713+0.744 \mathrm{X}$ means that every increase of 1 unit of work environment will increase 0.744 employee turnover unit intention of 4-star hotel in Padang City. Keywords: work environment, turn over intention, employee.
\end{abstract}

\section{INTRODUCTION}

\subsection{BACKGROUND}

The progress of the development of the business world is currently experiencing a very rapid increase compared to the previous era, this can be seen in terms of the company's contribution to the Indonesian economy. In facing world competition, each company must have a special way so that the company's existence will run smoothly and the company's goals can be maximally achieved, especially managing the human resources of the company.

Padang City is one of the tourist destinations that are considered to be growing and developing rapidly, moreover the city is improving to develop its tourism industry, as seen from the many events held by the city government. The city government of Padang expects that with all its potential it can be an attraction for tourists to visit and ultimately can improve the economy of this city. In carrying out tourism activities, tourists need accommodation that will support tourist activities. Lodging is one of the accommodations needed by tourists in carrying out their activities, but not only services from lodging that tourists need, but other supporting services also affect the needs of tourists. So lodging that provides other services to support tourist travel is also needed, one of the accommodations is the Hotel. 
Hotels have become an important requirement for people when visiting an area or a country as a place to rest. The hospitality business is not only for lodging activities but also for restaurant services, conventions, meeting packages. According to the Republic of Indonesia Minister of Tourism and Creative Economy Regulation No. 2 of 2014 Article 1, hotels are providing accommodation in the form of rooms in a building that can be equipped with food and drink services, entertainment activities and other facilities on a daily basis in order to obtain profits.

HR management is an important activity in an organization. Organizations need to regulate HR to achieve goals effectively, by always doing with always making investments to receive, select, and retain potential HR so as not to have an impact on the movement of employees (Anis et al., 2003).

In fact, managing HR for a company is not an easy thing to do, many HR management problems are found in practice. One of the problems that often occur in a company is related to turnover or the level of entry and exit of employees in a company, this problem can continuously cause new problems called turnover intention or the tendency of employees to go in and out of the company.

Saeed, et al (2014), said that turnover intention is a serious thing that is currently happening, where employees are interested in leaving organizations or organizations interested in firing their employees. Turnover by employees voluntarily is when employees are intent on planning to leave the organization or company to choose the best alternative path for their future. While turnover is voluntary, that is, when the organization or company is not satisfied with the employee's turnover intention and decides to dismiss it.

There is an opinion that the employee turnover ratio of a company is beyond the tolerance limit when it reaches $10 \%$ or more within one year. According to Roseman (1981), one of them is, if the annual turnover in a company reaches $10 \%$, then the company's turnover category can be said to be high. The following are data on employee turnover conditions at 4-star hotels in the city of Padang as follows:

Table 1. Percentage of Employee Turnover of 4 Star Hotel in Padang City

\begin{tabular}{|c|l|c|}
\hline No & \multicolumn{1}{|c|}{ Hotels } & $\begin{array}{c}\text { Turn Over } \\
\text { Percentage }\end{array}$ \\
\hline 1 & Hotel Rocky Plaza & $17,95 \%$ \\
\hline 2 & Hotel Axana & $19,42 \%$ \\
\hline 3 & $\begin{array}{l}\text { Hotel Kyriad } \\
\text { Bumiminang }\end{array}$ & $33,70 \%$ \\
\hline 4 & Hotel Grand Inna & $3,39 \%$ \\
\hline 5 & Hotel Premier Basko & $16,30 \%$ \\
\hline 6 & Hotel Mercure & $24,39 \%$ \\
\hline 7 & Hotel Pangeran Beach & $3,31 \%$ \\
\hline
\end{tabular}

Source : Human Resources Department of 4 Stars Hotel, Padang, Januari 2018

From Table 1 above it is found that the turnover rate in 4-star hotels in the city of Padang is high because it exceeds $10 \%$. The percentage categorized as a low 
turnover rate is only 2 hotels from 7 4-star hotels in Padang, namely the Grand Inna Padang Hotel and the Pangeran Beach Hotel. Whereas the other 6 hotels have high turnover rates exceeding $10 \%$.

The relatively high annual turnover rate is a case where companies find it difficult to develop employee retention programs. Retention program according to Mathis (2006), is a program that is owned by the company to maintain potential employees owned by the company to remain loyal to the company. The purpose of the company is to retain employees who are considered quality from the company at the will of the employees themselves.

The following factors are mentioned by (Pasewark and Strawser (1996) in (Toly, 2001) as determinants of turnover intention one of which is job satisfaction and also influenced by financial compensation and work environment. Financial compensation and work environment as factors that influence satisfaction work and also have a direct effect on turnover intention.

The purpose of this study was to analyze the influence of the work environment on the turnover intention of 4-star hotel employees in Padang City.

\subsection{Research Problems:}

Based on the background and limitations of the problems that the researchers have mentioned above, the formulation of the problem of this research is:

a. Does the work environment influence the employee's turnover intention of 4-star hotel

\subsection{Research Purposes}

The specific purposes of this research are:

a. For identifying the contribution of work environment toward employee's turnover intention of 4 Star hotels in Padang City

\section{Turnover Intention}

\section{LITERATURE REVIEW}

to Saeed et al (2014), turnover intention is a situation where employees of an organization have a plan to leave work, or a condition in which the organization has a plan to terminate employment with employees. In another opinion, Siregar (2006: 214) turnover intention is, "the tendency or intention of the employee to stop working from his job voluntarily according to his own choice". Robbins (2006) defines turnover as the termination of employees who are permanent from the company whether done by the employee itself or by the company.

Turnover intention in the opinion of one expert, Mobley (2002: 44): "an important phenomenon of organizational life". Booth and Hamer (2007) argue that, turnover intention is the worst impact of the inability of an organization in managing an individual's behavior so that individuals feel they have the intention to move to a high job. Thus, according to severe experts above can be concluded that the notion of turnover intention is a phenomenon or condition of members of an organization that has a plan to leave members of the organization to move to other organizations on the wishes of the individual itself, or the conditions in which the organization intends to end the relationship work with these members because the organization feels dissatisfied with the performance of its members ". 
According to Chen and Francesco (1978) in Widodo (2010), indicators of turnover intention measurement consist of: 1) thoughts to leave, 2) desire to find another job, 3) desire to leave the organization.

From the above opinion it can be concluded that employee performance in research is a phenomenon or condition of members of an organization that has plans to leave members of the organization to move to other organizations on the wishes of the individual itself in this study for 4-star hotel employees in Padang City.

\section{Work Environment}

Sedarmayanti (2011) reveals the work environment is the entire tooling equipment and materials faced, the surrounding environment where a person works, work methods, and work arrangements both as individuals and as a group. The same thing is also expressed by Nitisemito (1996) who defines the work environment as everything that exists around workers who can influence themselves in carrying out their assigned tasks. Therefore, the determination and creation of a good work environment will determine the success of achieving organizational goals.

A work environment is a place where someone does his work activities every day. A conducive work environment, allows one to work more optimally. Sims and Kroeck (1994) in Rego \& Cunha (2008) states that the determinants of individual performance in organizations are individual factors and environmental factors, they also explain that someone chooses to work in an organization / company with a work climate that is suitable for his desires.

A comfortable work environment for employees can increase morale and encourage better performance and employees stay afloat. Sedarmayanti (2011) states that broadly speaking, the type of work environment is divided into 2, namely the physical work environment and the non-physical work environment.

Based on the above theory it can be concluded that the work environment is everything that exists around the workers who can influence themselves in carrying out the tasks assigned.

\section{RESEARCH METHOD}

\subsection{Type of Research}

This research was conducted with quantitative descriptive with associative causal approaches.

\subsection{Research Respondents:}

In this study the population was 796 people consisting of all 4-star hotel employees in the city of Padang, with the determination of the sample based on the type of probability sampling used was proportional random sampling. to the opinion of Slovin (Umar, 2011: 78) at 5\%. from the calculation results obtained a sample of 251 people.

\subsection{The technique of Collecting Data}

The types and sources of data in this study use primary data and secondary data. Data collection techniques in this study were carried out through 
questionnaires and documentation. The instrument in this study was to use a questionnaire with a Likert scale. Before the questionnaire was used, the validity test and the real test were first carried out. The data analysis technique in this study uses simple linear regression analysis.

\subsection{Technique of Analyzing Data}

The data analysis technique in this study uses simple linear regression analysis. Before using a simple linear regression analysis a prerequisite test was carried out, namely the test for normality, homogeneity and linearity. From the normality test, the data is normally distributed. Then the homogeneity test obtained results that the data originated from populations that have the same variance or homogeneous data. And the linearity test obtained results that linear data. From the results of the test it meets the requirements to use simple linear regression analysis.

\section{THE FINDINGS AND DISCUSSION}

Before using a simple linear regression analysis a prerequisite test was carried out, namely the test for normality, homogeneity and linearity. From the normality test, the data is normally distributed. Then the homogeneity test obtained results that the data originated from populations that have the same variance or homogeneous data. And the linearity test obtained results that linear data. From the results of the test it meets the requirements to use simple linear regression analysis. The hypothesis testing in this study used a simple linear regression technique with the help of the SPSS 23.00 program. The following are the results of hypothesis testing in this study.

Table 2. Coefficient of Determination

\begin{tabular}{|l|l|r|r|r|}
\hline & & & & \\
\hline $\begin{array}{l}\text { Mod } \\
\mathrm{el}\end{array}$ & $\mathrm{R}$ & $\begin{array}{c}\mathrm{R} \\
\text { Square }\end{array}$ & $\begin{array}{c}\text { Adjusted } \\
\text { R Square }\end{array}$ & $\begin{array}{c}\text { Std. Error } \\
\text { of the } \\
\text { Estimate }\end{array}$ \\
\hline 1 &, $556^{\mathrm{a}}$ &, 309 &, 307 & 3,86557 \\
\hline
\end{tabular}

$$
K P=r^{2} \times 100 \%=0,309 \times 100 \%
$$

$\mathrm{R}$ square $=0.309$, meaning that the contribution or influence of the work environment variable on the employee turnover intention of 4-star hotels in Padang City is $30.9 \%$, while $69.1 \%$ is determined by other factors.

The value of $\mathrm{F}$ counts 111,548 with sig. $0,000<0,05$, meaning that the work environment variable can explain employee turnover intention significantly. 
Table 5. Coefficient Regression of Variable X Regression toward Variable Y

\section{Coefficients}

\begin{tabular}{|c|c|c|c|c|c|}
\hline \multirow[b]{2}{*}{ Model } & \multicolumn{2}{|c|}{$\begin{array}{c}\text { Unstandardized } \\
\text { Coefficients }\end{array}$} & \multirow{2}{*}{$\begin{array}{l}\text { Standa } \\
\text { rdized } \\
\text { Coeffi } \\
\text { cients } \\
\text { Beta }\end{array}$} & \multirow[b]{2}{*}{$\mathrm{t}$} & \multirow[b]{2}{*}{ Sig. } \\
\hline & B & $\begin{array}{l}\text { Std. } \\
\text { Error }\end{array}$ & & & \\
\hline $\begin{array}{ll}1 & \text { (Consta } \\
\text { nt) }\end{array}$ & $\begin{array}{r}15,71 \\
3\end{array}$ & 2,393 & & 6,567 & ,000 \\
\hline $\begin{array}{l}\text { Lingku } \\
\text { ngan } \\
\text { Kerja }\end{array}$ &, 744 & ,070 & ,556 & 10,562 & ,000 \\
\hline
\end{tabular}

a. Dependent Variable: Y

From Table 5 above the regression equation is obtained as follows:

\section{$\mathbf{Y}=\mathbf{a}+\mathbf{b X}=\mathbf{1 5 . 7 1 3}+\mathbf{0 , 7 4 4} \mathrm{X}$}

Based on the table above, it is obtained a constant value (a) of 15,713, this number means that if there is no work environment $(\mathrm{X})$, the value of the employee's consistent turnover intention (Y) is 15,713 . Then the regression coefficient value (b) is obtained at 0.744 , this number means that every $1 \%$ increase in environmental level $(\mathrm{X})$, then turnover intention $(\mathrm{Y})$ will increase by 0.744 .

\section{DISCUSSION}

\section{The Effect of Work Environment on Employee Turnover Intention in 4-Star Hotels in the City of Padang}

The work environment has a positive effect on the employee turnover intention of 4-star Hotels in Padang City with a regression coefficient of 0.744, this means that if there is an increase in the value of the work environment by one unit it will improve employee turnover by 0.744 units and vice versa. Then it can be said that the better the non-physical and physical work environment that is felt by the individual, the better it will be the more comfortable the employee works so that turnover intention is also getting better which means there is a decrease in turnover rate. This means that the work environment has a significant effect on the turnover intention of 4-star hotel employees in the city of Padang, because a bad working environment will increase the desire of employees to leave.

The results of the study also showed the contribution of work environment variables to the turnover intention of 4-star Hotel employees in the City of Padang, which amounted to $30.9 \%$. So a conducive work environment will improve the turnover intention of 4-star Hotel employees in Padang City.

This research is in accordance with Andi Caezar To Tadampali's research, et al. 2016 about the Effect of Organizational Climate on Turnover Intention 
Through Job Satisfaction As Intervening Variables in PT Bank SULSELBAR which states that turnover intention is influenced by the work environment.

\section{CONCLUSION AND SUGGESTION}

\subsection{CONCLUSION}

Based on the results of the study, the conclusions that can be taken care that there is significant influence between the work environment on the turnover intention of 4-star hotel employees in the city of Padang. A conducive work environment will improve the turnover intention of 4-star hotel employees in Padang City.

\subsection{SUGGESTIONS}

Based on the results of the study, then there are some suggestions that the authors submit to hotel management to improve the turnover rate, as follows:

Always build a conducive work environment through emphasis on goals in a way: a. $\quad$ Creating a harmonious non-physical work environment.

b. Paying attention to the physical work environment of employees at work.

\section{BIBLIOGRAPHY}

Andini , Rita (2006) ANALISIS PENGARUH KEPUASAN GAJI, KEPUASAN KERJA, KOMITMEN ORGANISASIONAL TERHADAP TURNOVER INTENTION (Studi Kasus Pada Rumah Sakit Roemani Muhammadiyah Semarang). Masters thesis, Program Pasca Sarjana Universitas Diponegoro.

Aydogdu, S., \& Baris, A. 2011. International Review of Management and Marketing An Empirical Study of the Relationship Among Job Satisfaction, Organizational Commitment and Turnover intention, 1(3), 43-53.

Chen, C.-F. 2006. Job satisfaction, organizational commitment, and flight attendants' turnover intentions: A note. Journal of Air Transport Management, 12(5), 274-276. doi:10.1016/j.jairtraman.2006.05.001

DEVI, Ni Luh Mita Sri; SUDIBIA, Gede Adnyana. Analisis Pengaruh Job Insecurity, Dan Kompensasi Finansialterhadap Kepuasan Kerja Dan Turnover Intention: (Studi Pada Karyawan Kontrak Di Bali Dynasty Resort). E-Jurnal Manajemen Universitas Udayana, [S.1.], v. 4, n. 4, apr. 2015. ISSN 2302-8912. Available at: <https://ojs.unud.ac.id/index.php/Manajemen/article/view/11586>. Date accessed: 04 oct. 2018.

DHERMAWAN, Anak Agung Ngurah Bagus; SUDIBYA, I Gde Adnyana; UTAMA, I Wayan Mudiartha. PENGARUH MOTIVASI, LINGKUNGAN KERJA, KOMPETENSI, DAN KOMPENSASI TERHADAP KEPUASAN KERJA DAN KINERJA PEGAWAI DI LINGKUNGAN KANTOR DINAS 
PEKERJAAN UMUM PROVINSI BALI. Matrik : Jurnal Manajemen, Strategi Bisnis dan Kewirausahaan, [S.1.], aug. 2012. ISSN 2302-8890. Available at: <https://ojs.unud.ac.id/index.php/jmbk/article/view/2203>. Date accessed: 04 oct. 2018

Kaswan. 2012. MSDM untuk Keunggulan Bersaing Organisasi.

Mathis, Robert L., dan John H., 2006. Manajemen Sumber Daya Manusia, PT.Salemba Emban Patria, Jakarta

Mosadeghrad, A. M., Ferlie, E., \& Rosenberg, D. (2008). A study of the relationship between job satisfaction, organizational commitment and turnover intention among hospital employees. Health Services Management Research: An Official Journal of the Association of University Programs in Health Administration / HSMC, AUPHA, 21(4), 211-27. doi:10.1258/hsmr.2007.007015

Noe, R. A., Hollenbeck, J. R., Gerhart, B., \& Wright, P. M. (2014). Fundamentals of Human Resources Management (5th ed.). Mc Graw Hill.

Robbins, S. P., \& Judge, T. A. 2013. Organizational Behavior (15th ed.). New Jersey: Pearson Education, Inc.

Roseman, E. 1981. Managing Employee Turnover: APositive Approach. New York: AMACOM.

Saeed, Iqra., Waseem, Momina., Sikander, Sidra., Rizwan, Muhammad. 2014. The relationship of Turnover intention with job satisfaction, job performance, Leader member exchange, Emotional intelligence and organizational commitment. International Journal of Learning \& Development, 2014, Vol. 4, No. 2.

Sedarmayanti. 2001. Sumber Daya Manusia dan Produktivitas Kerja. Bandung: Mandar Maju.

Sedarmayanti. 2011. Tata Kerja dan Produktivitas Kerja. Bandung: Mandar Maju.

Syah, H. 2013. Pengaruh Kompensasi Finansial Terhadap Kepuasan Kerja Dan Motivasi Kerja Karyawan Pada Pt . Graha Raja Empat Harits Syah Jurusan Manajemen , Fakultas Ekonomi , Universitas Negeri Surabaya Kampus Ketintang Surabaya 60231. Jurnal Ilmu Manajemen, 1, 462-471.

Toly, A. A. 2001. Analisis faktor-faktor yang mempengaruhi. Jurnal Akuntansi \& Keuangan.

Umar, Huesin. 2011. Metode Penelitian Untuk Skripsi dan Tesis. Jakarta: PT. Grafindo Persada 